\title{
The Community-Enterprise Trademark and Packaging Design in Ban Dung District in Udonthani, Thailand
}

\author{
Rosjana Chandhasa ${ }^{1}$ \\ ${ }^{1}$ Faculty of Industrial Technology, Department of Industrial Design, Suan Sunandha Rajabhat University, Thailand \\ Correspondence: Rosjana Chandhasa. Tel: 66-955-181-285. E-mail: rosjana.ch@ssru.ac.th
}

Received: August 24, 2017

Accepted: October 2, 2017

Online Published: October 28, 2017

doi:10.5539/ass.v13n11p59

URL: https://doi.org/10.5539/ass.v13n11p59

\begin{abstract}
This study aims to analyze problems and marketing situations of an original community-enterprise product in Ban Dung, Udonthani in order to create and develop new trademark and product packaging as well as to evaluate the market test in developing the community-enterprise trademark and merchandise package in Ban Dung, Udonthani. The target group consists of 10 community enterprises in Ban Dung district in Udonthani province using interview format regarding the obstacles, marketing situations as well as a trademark and packaging demand.

The participants also include 400 citizens and travelers questioned by using the original-package assessment. The research result elucidates that the problems and marketing situations involve with these following internal factors which are: personnel section concerning about the unity of members in the community enterprises, management section which covers a potential of the community enterprises in producing products themselves, using local materials as well as varying their own products, and marketing section which is facing with lacking a permanent shop. In addition, there is also an external factor comprising of economic section that causes serious consequences as well as higher-competitor circumstance. Therefore, the mentioned factors resulted in the trademark and packaging improvement.

The community-enterprise trademark and product packaging design in Ban Dung, Udonthani demonstrates that the trademark is a marketing necessity in capturing consumer attention by its brand name as well as logo. The name should be able to represent the area, such as Kham Chanod, the Great serpent, the naga lord Sesotho in order to be easy to remember. The graphic design should emphasize the unity, balance and dominance to clarify the trademark pattern as well as have an identity which relates to the brand name. The packaging should be designed in order to utilize easily with an affordable production cost; moreover, it should be able to protect the product as well as sell itself. According to the packaging appearance, there is a visible part to show merchandise inside in order to efficiently gain consumers' decision. It also has to be considered durability, strength and affordability. The original-package assessment result exhibits that there is the highest level of overall satisfaction towards community-enterprise product packaging) Mean =4.88) underlying about the package while transporting from production sources to market. The package should suit to transport, otherwise it may affect product inside. The defective product will be harder to sell. Meanwhile, there is a high level of satisfaction towards the product collected data from people and traveler in Udonthani (Mean =3.98) emphasizing the beauty of the product initially.
\end{abstract}

Keywords: Trademark, Packaging, Community Enterprise in Ban Dung in Udonthani

\section{Introduction}

Udonthani "Udonthani the livable city, supports arts and culture, agriculture industry, advances in education, and develops tourism" which is in accordance with the commercial provincial development strategy about a fundamental project improvement promotion in order to enhance a product quality to conform with the market requirement as well as to create a logo in order to increase efficiency and value of SMEs' and community enterprises' goods based on personnel development and management administration knowledge. Additionally, it is also consistent with OTOP product development strategy which improves a product quality and its standard, promotes creating logo, registers the intellectual property rights, encourages local-material usability as well as adds value to the product by emphasizing an entrepreneurial group plus upcoming networks. These can elevate the competency of production and competition in community product development policy movement in 
increasing its value by holding a creative economy principle. The creative economy is a goods and service innovation. The creativity is properly hyperlinked as well as integrated the cultural foundation, technology, society and living together. According to the economic competition, the national strength has to be investigated and brought up to use through the thinking process which initiate the historical, traditional and cultural capitals; moreover, the ideas is subsequently further developed to adapt in adding value of merchandise and services which are nowadays economic mechanism. Notably, only developing product quality at present is inadequate due to a high marketing competition of community-enterprise competitors, private ownerships, as well as factories or companies which produce similar-typed products. Hence, the community-enterprise product producer promotion and support have to depend on both state and private agencies in proceeding. In addition, the production management and product advancement have to promote the distribution, trademark creation as well as packaging development.

Trademark and package can outstandingly be an advertising media; they are also able to promote sales at the selling point. They seem to be a key to unlock the door of purchase decision. Kiadthong, T. (2005) had claim about packaging and trademark that there is a trademark or more on one packaging. It is important to the product package as it makes consumers can memorize the name and its unique logo, and shopkeepers usually takes the designed brand name to register as a trademark in order to protect their product rights. Soodsang, N. (2016) said the development of label and package considers a number of problems observed in previous package designs. They did not serve full functionality with such as the problem of internal structure to protect goods. They also did not provide expected marketing advantages as they failed to represent the local uniqueness for distribution, and less attractive to motivate consumers' decision to purchase the product.

The next phase of development direction will focus on knowledge based economy structure which highlights creativity as well as innovation. Creating products and innovating services by concerning environment and community friendly principles according to creative economy as well as green economic affairs are another way of increasing national economic value and praising Thai ness pride; whereas, the competition systems should be freely and fairly launched. Furthermore, overall image of economic stability should be maintained to suit the economic structure reforming so that it will grow appropriately, permanently, extensively, fairly, steadily and efficiently as well as to comply with the Udonthani commercial strategic planning. The provincial strategy will be reached by contemplating and linking E-san production sources together in order to present development ideas of local wisdom upgrading which can flourish a community, and help people in the community have a better life by changing the production and local resource management into quality products which have a striking identity representing the community, and are in accordance with culture in each area.

The products are based on local yet global, self-reliance-creativity and human resource development. The products do not only refer to the goods for sale, but also include thinking and creating processes, local-wisdom and custom preserving, product developing in boosting its quality and notability and famous shops which are known in both national and world level. Thus, increasing value of the products produced by community enterprises in Ban Dung, Udonthani in packing process, improving product appearance, packaging design, creating a trademark which can meet the market demand and increase the turnover, and as well as developing grassroots economic development to be continually sustainable.

\section{Research Objectives}

1. To analyze problems and marketing situations of an original community-enterprise product in Ban Dung, Udonthani.

2. To create and develop a trademark and product packaging of the community enterprises in Ban Dung, Udonthani.

3. To evaluate a market test in developing trademark and packaging of the community enterprise in Ban Dung, Udonthani.

\section{Research Methodology}

The community-enterprise trademark and packaging design in Ban Dung, Udonthani begins with the qualitative method on searching for the existing products by gathering data from an in-depth interview format; in addition, the result will be summarized as a document form in order to be analyzed and sync the sized concordantly with the marketing situations to create and develop the packaging to response a market demand. According to the background and statement of the problems, the packaging assessment will be evaluated by consumers using quantitative research method. Besides, the researcher arranges the criteria as following: population and sample, research instrument, research methodology, product development and data collection.

\subsection{Population and sample}

Population is citizens and traveler in Udonthani province, the producers in the community enterprise who have 
producing experience at least 10 years as well as samples from a purposive sampling technique which are:

1. Population sample: dwellers and visitors in Udonthani totaled at 400 people whom are questioned to gain packaging requirement. They are purposive sample from the souvenir shops at 2 well-known tourist attractions in Udonthani in order to collect data of consumers' demand properly. The tourist attractions consist of 1.the OTOP Civil-State store in the Udonthani international airport 2. The Community Economic Service Center in Ban Dung district in Udonthani province.

2. The community merchandises "Ban Dung Models" in Udonthani: 10 groups of shopkeeper are targeted using purposive selection, and divided into food and herb, beverage, appliance as well as clothes. Additionally, the shopkeepers should experience in producing community products at least 10 years as well as run business 3 years or more.

3. Users (citizens and travelers in Udonthani) the dwellers and visitors in Udonthani totaled at 400 people are conducted package need assessment. They are purposive sample from the souvenir stores at 2 famous tourist attractions in Udonthani in order to collect data of consumers' demand properly. The tourist attractions are 1. the OTOP Civil-State store in the Udonthani international airport 2. the Community Economic Service Center in Ban Dung, Udonthani.

\subsection{Research Instrument}

The research instruments used in gathering data in an operation process according to the research objectives are separated as following:

1. In regard to the contemplating problems and marketing situation of the original community-enterprise products in Ban Dung, Udonthani, the researcher uses these subsequent instruments which are:

(1) A structured interview format used for interview producers about the original products and their production.

(2) Close ended questionnaires attached with photos are used to conduct the survey of citizens' and travelers' satisfaction toward the original product. The collected data will involve with opinions about the identity as well as the ideal product to be adapted in the design procedure. The questionnaire format including check lists, rating scales and open ended questions in order to acquire suggestions to investigate, develop and apply in creating trademark as well as product package.

(3) The result will be analyzed using SWOT approaches in order to gain appropriate information concerning consumers' need as well as producers' obstacle and demand before designing.

2. Creating and developing trademark and packaging of the community enterprise in Ban Dung district, Udonthani have to comply with the 10 groups of market requirement After providing product models as well as designing evaluation forms in order to measure producers' and community enterprises' satisfaction toward the products and their packages. The criteria in measuring the satisfaction are:

(1) Need / Benefit

(2) Form

(3) Technology

3. The market test assessment of community-enterprise trademark and packaging in Ban Dung in Udonthani will be an idea for the producers to adapt the consumers' satisfaction towards recreated and developed package in food packaging design. The questionnaires to measure the consumers' aspect consist of:

1. Usability testing/marketing testing

1.1 Transportation

1.2 Targets-Group Acceptance in Real Selling Situation

1.3 Durability

1.4 Goods with Developed Packaging Satisfaction Evaluation

2. Aesthetic Function

2.1 Beauty of Composition

2.2 Value and Price

2.3 Uniqueness and Interestedness 


\subsection{Research Design (Questionnaire)}

1) Brief study about problems and needs of producers, consumers and community enterprises in Ban Dung, Udonthani.

2) Research Literature Review regarding product development, trademark creation and packaging design in order to be able to comprehend the design and development as well as can create for utilizing beautifully and suitably.

3) Design questionnaire and evaluation formats

4) Check the accuracy of the language, typing and texts as well as the propriety and compatibility between contents in questionnaires and indicated objectives.

\subsection{Data Collection}

Recording the observation data into a note book and coexisting attaching photos can be summarized as well as arranged as following:

1. The civil society forum is held in order to discuss about problems as well as the satisfaction of producer, consumers and community enterprises in Ban Dung district, Udonthani to acquire deep information regarding problems, requirements and product forms.

2. The close-ended questionnaires are used to conduct survey of customers' satisfaction and marketing demand information to adapt in designing process. Besides, the open-ended questionnaires are used to gain the suggestions in order to consider and apply in product and packaging development.

3. Questionnaires and duplicates of product forms, trademark as well as packaging are used to illustrate the design ideas to producers. They will help the producers understand the forms which can benefit answering the questionnaires correctly as well as creating products properly and beautifully.

4. According to the market test, an evaluation format is used to acquire a satisfaction of citizens and travelers in Udonthani towards the developed products in order to be an idea for producers in producing products. Afterwards, overall information will be concluded and written as a report.

\section{Conclusion of Research Results}

Regarding the trademark and packaging design of community enterprises in Ban Dung, Udonthani, the researcher encapsulates its results by holding the objectives which are:

1. The research result shows that the problems and marketing situation of the original community-enterprise product in Ban Dung, Udonthani has a potential to sell goods as well as reach the top-rank distribution of Ban Dung. Moreover, it is exhibited that 7 of 10 community enterprises have a similar thought involving emphasizing the remarkableness of trademark and packaging which can be outlined as following:

2. For distribution channels, every group highlights a wholesaling to other shops inside and outside the province as well as opening booth in festivals; however, there are 3 groups of producers which have a new-generation leader, and sell merchandises via Facebook and Line.

3. General problems which every group faces are budget-support scarcity as well as lacking of convenient transportation and out-of-date product appearance; therefore, the producers want relevant government sectors to help in developing products as well as acknowledging more information. Additionally, there are 2 groups of producer which are Kluay-City Organic Agricultural Group (Riceberry Rice Group in Ban Kluay) and Udon-Nakin Fabric Group. These producer groups can create new products; they also dare to initiate and trial to get new innovations.

4. The targeted things to improve are trademark as well as packaging by proceeding SWOT analysis which involve with comparison and selection considering internal and external factors which effectuate the design development. The SWOT analysis can be presented as following: weakness. It can be developed and the solutions from suggestions are recommended to community enterprises. Internal factor directly relates to an upholder, and can be controlled more or less depending on proficiencies as well as resources which are results of strength and solved in overall image as following: 


\section{STRENGRHS}

1. Members are strong an dunite.

2. There are various types of product.

3. Materials and equipment are well prepared.

4. The woven fabric groups can dye cloth using natural color and test color themselves.

5. There're various marketing channels today.

6. There are customers continuously and all-time new products creation.

7. Rice production group can produce, husk and subsidize rice itself. There is annually field check for GAP standard and $100 \%$ own production.

8. All goods available are self-production, no import.

\section{WEAKNESS}

1. Slow product development can't meet market demand.

2. High production, but low sale; products are unknown.

3. Lack of budget and specific tools

4. There is no permanent shop or own store.

5. Form and color is out-of-date.

6. Lack of further development

7. The textile product has a problem with natural dye-color durability.

8. Rice production and herbal beverage group lack of ideas in packaging development and knowledge about producing quality rice and drinks.

\section{OPPORTUNITES}

1. Diverse marketing channels

2. Government sectors help to further develop on both marketing and skills.

3. There are export channels, transportation and E-commerce technology

4. The products can be pre ordered and developed in up-to-date ways.

\section{SWOT}

\section{THREATS}

1. Slow production and late budget

2. High production, but low sale

3. There is no market available.

4. Economic recession

5. The competitors are upholders who like to copy product production ideas.

6. Rice and Herbal drinks face with season problems, crop price and professional faith of people in community.

7. Consumers depreciate the handicraft, and conserve Thai handcraft; admire foreign products.

Figure 1. The SWOT analysis

1. Personnel factor: the leader plays an important role in encouraging, supporting and giving equality to build strength and unity to members in community enterprise. Moreover, the leader should also allocate members' revenue fairly. Regarding skill development, the producers have to be willing to acquire knowledge, thought as well as new producing procedures. In addition, they have to participate in training and meeting held by government sectors including Community Development Department of district and province, Department of Export Promotion, Department of Skill Development as well as university which always launch seminars to improve the potential.

2. Management factor: the community enterprise should always plan in advance for a month. The meeting should be held not less than 2-3 times in order to let members cooperatively make plans as well as discuss what to do, when, how, what equipment should be purchased, where to sell grab out finance, accounting, income and expenditure issues.

3. Marketing factor: the customer's demand and service approaches will be considered to respond satisfaction of users as well as make money concordantly.

4. Packing, trademark and package factor: it is important to the product distribution and selection. In basic development model, all groups should considerably focus on materials and primary cost. For instance, the Kluay-City Organic Agricultural Group (Riceberry Rice Group in Ban Kluay) formerly has PP plastic bags for containing rice and industrial vacuum sealer; therefore, only creating sticker label for decorating bag should be done. The packaging production cost will be affordable; besides, the groups can co-operate with the relevant government sector which are: the product design major in the university, provincial community development department or the department of industry promotion. Meanwhile, the Sisotho group which is able to produce basketries can create box, basket or round bamboo basket (Cha-Lorm) for keeping clothes, and then attach a 
stamped tag. Hence, the production cost will be inexpensive, and can produce by the group itself.

External factor is a variable which is affected from outers. It is apart from what the upholders could control by themselves; nevertheless, it can be protect by well-prepared planning.

1. Economic factor: planning as well as setting revenue and expenditure should be managed coherently. In order to maintain the organization existence, there must be a contingency reserve to avoid the money crisis.

2. Competition factor: due to the fact that the community-product distribution has a high marketing competition between stores in the similar community and the opponents which is a private company, the product quality maintenance and standard price should be concern critically.

3. Resource factor: small businesses like to be spread around local areas, so it should be deliberated that the resources can be found easily or not because if the obtaining resource process is difficult and high-price, the production cost will be ultra-expensive as well as face a problem in competition.

4. Technology factor: normally, small businesses access a low technology or none which causes a short working effectiveness as well as useless high expenses. The machines are required; thus, it should request assistance from the government sector, such as the university which has a major relates to Mechanics or Engineering that can participate in basketry design research to respond the community-product production. It will benefit producers to acquire the machines which can support the producers' manufacture efficiently.

5. The research result of creating and developing trademark and packaging of the community enterprises in Ban Dung, Udonthani gathering data from 10 target groups. After the researcher verifies information and visits OTOP community, it is found that the producer group has a reliable production base as well as stable circulation totaled with 7 groups which are:

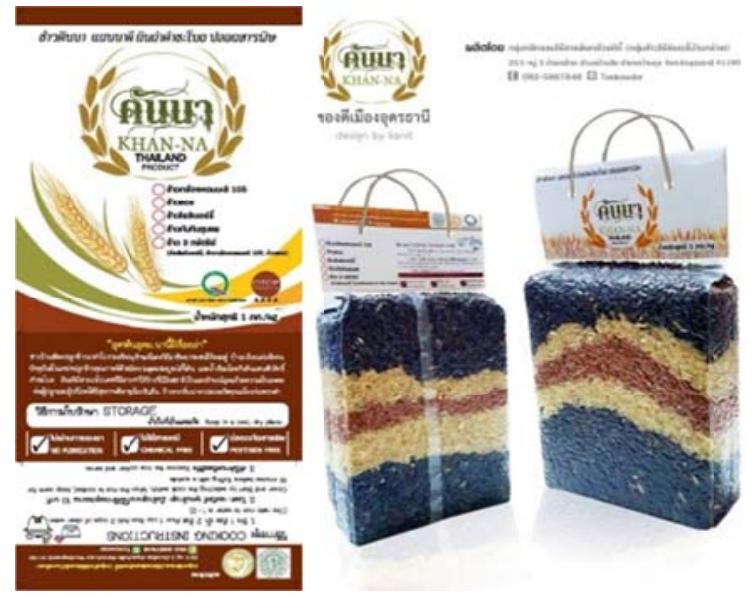

Figure 2. Kluay-City Organic Agricultural Group (Riceberry Rice Group in Ban Kluay), the group contains rice in the 10 kilogram vacuum bag

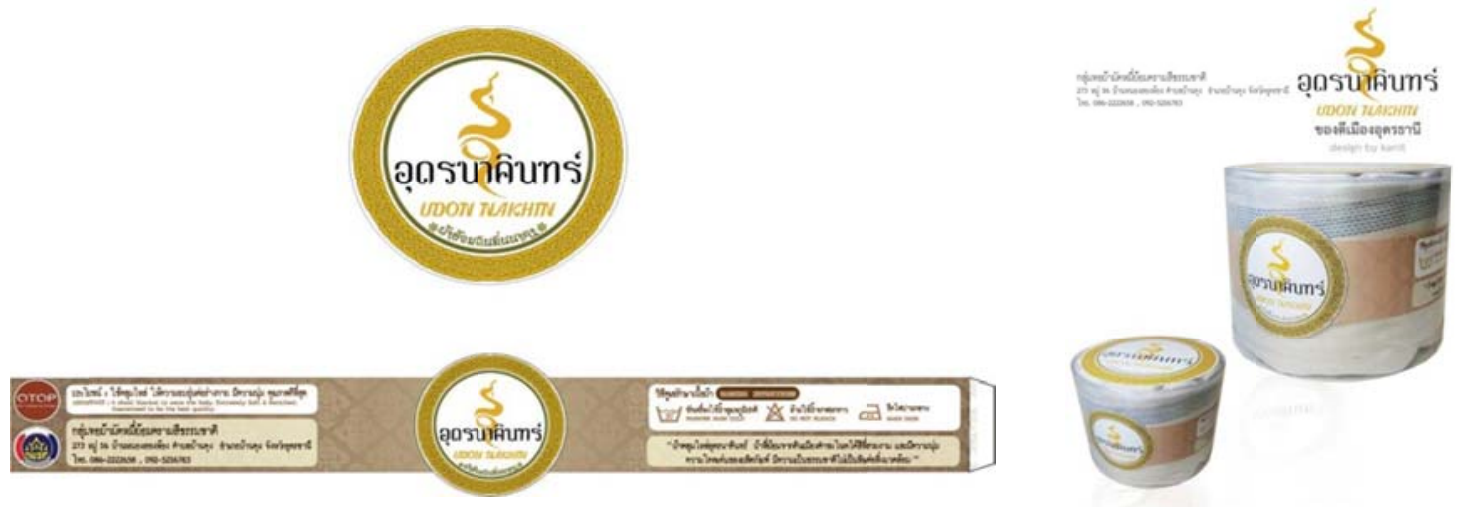

Figure 3. Udon-Nakin Fabric Group, the group dyestextile with natural soil of Kham Chanod. The production demand of the group isa packaging sticker and fabric packaging. The recreated packaging sticker and fabric packaging model of Udon-Nakin Fabric Group 

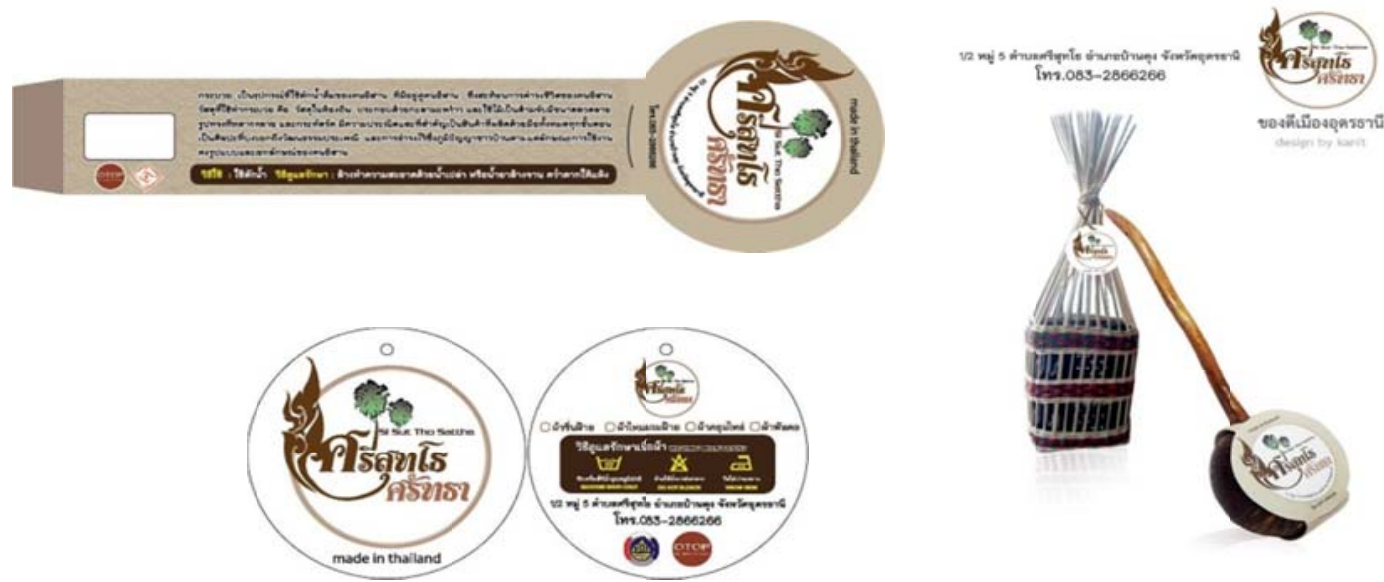

Figure 4. Sisotho-Satra Group, there are 2 types of product including coconut-shell product and processed clothes product. Product Tag, Sticker and Package Model Containing Coconut-Shell Product and Processed Clothes Product
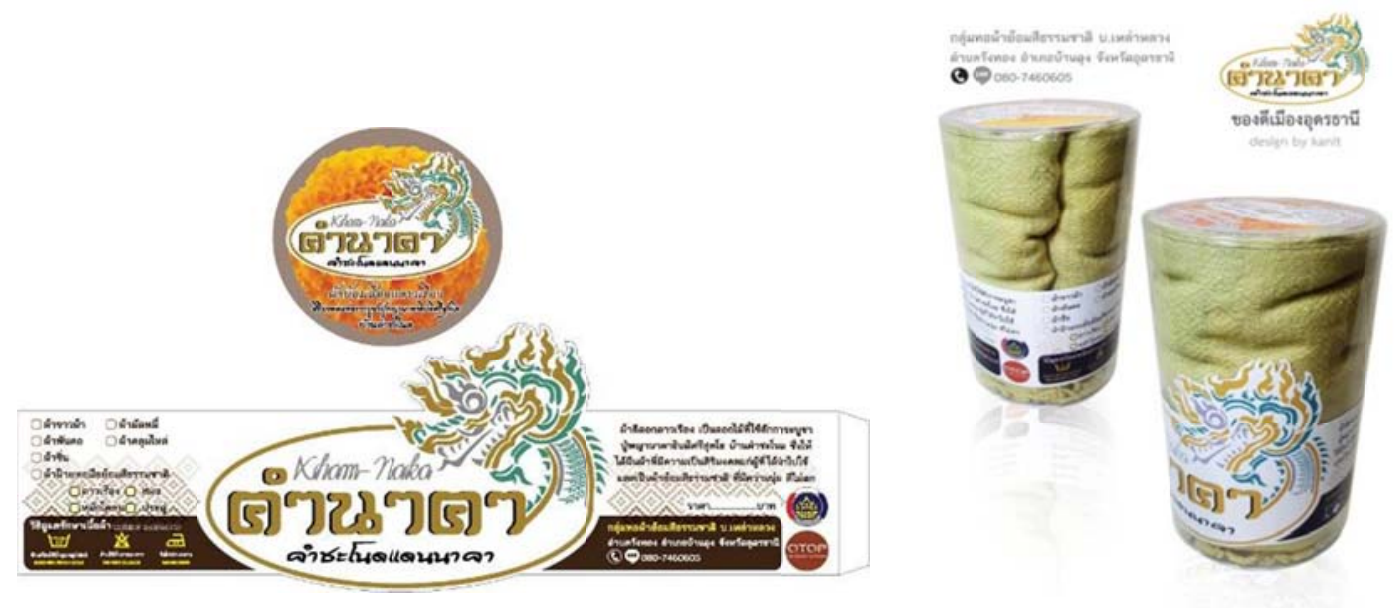

Figure 5. NaturalDye Woven Fabric Group in Lao Luang Village and NaturalDye Woven Cotton Textile Group. Pattern of MarigoldDye Fabric PackageforNaturalDye Woven Fabric Group in Lao Luang Village
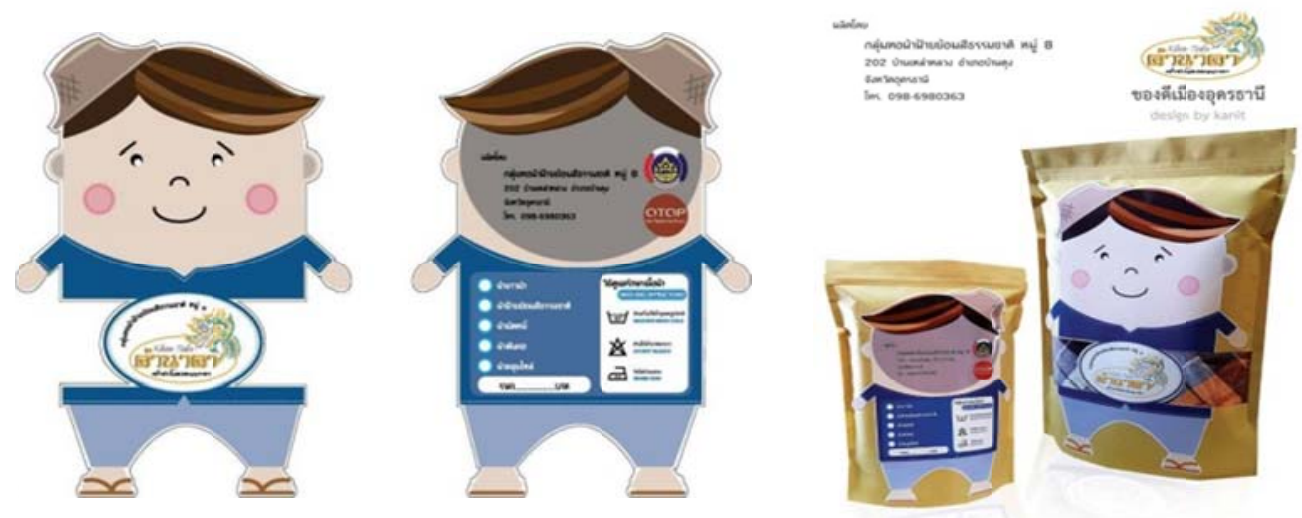

Figure 6. Pattern of ThaiLoincloth Package for Natural Dye Woven Cotton Textile Group 


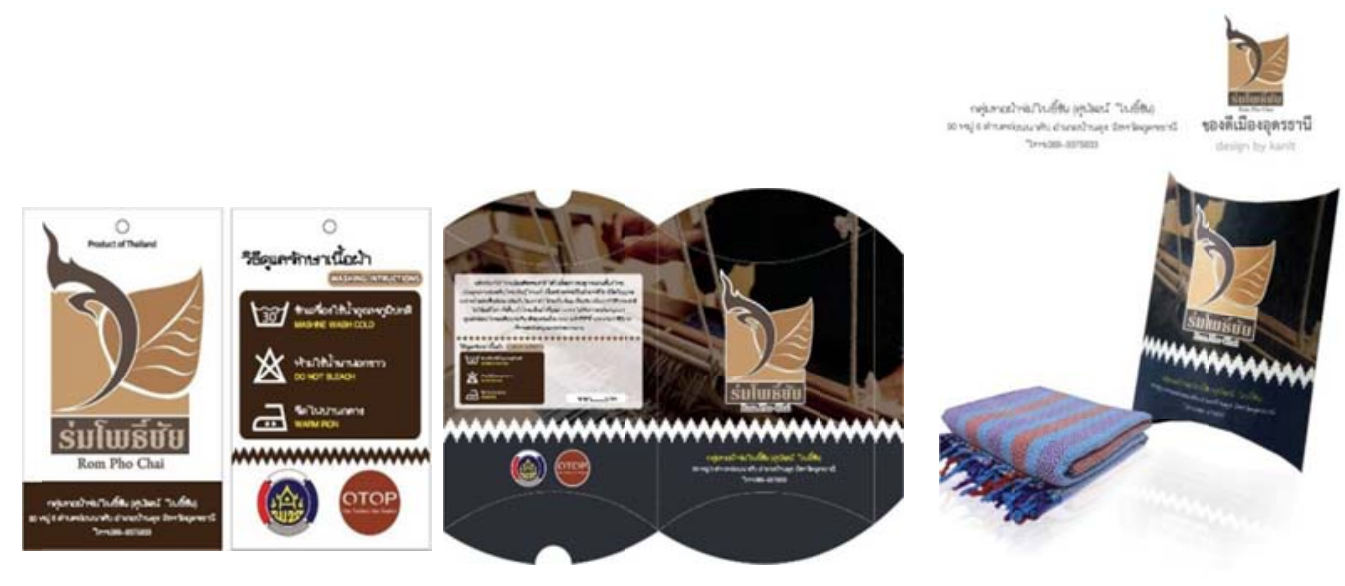

Figure 7. Mulberry Growing and Sericulture for Thai Ikat Woven Fabric Group is Natural Dye Silk Weaving Group (Cloth).Product Tag and Pattern of Cloth Package for Mulberry Growing and Sericulture for Thai Ikat Woven Fabric Group
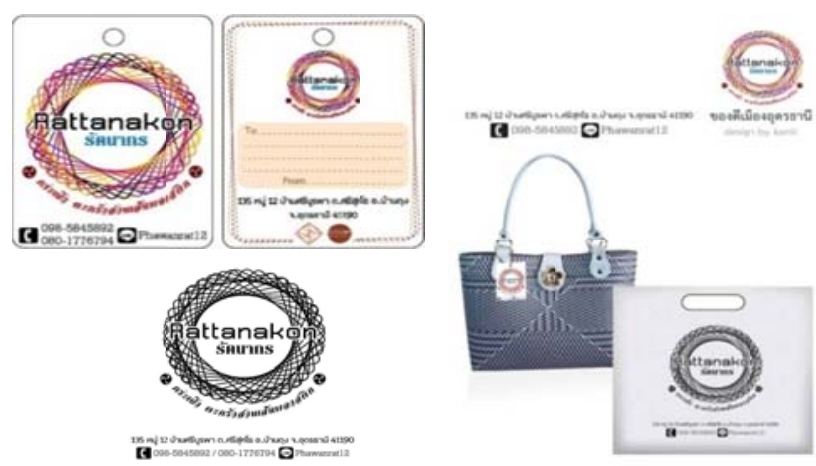

Figure 8. Product Tag and Pattern for Screen Printing on a Paper Bag. Bag and Plastic Interlaced Basket Group is a group which produces a basket, a bag as well as appliances from plastic fibers

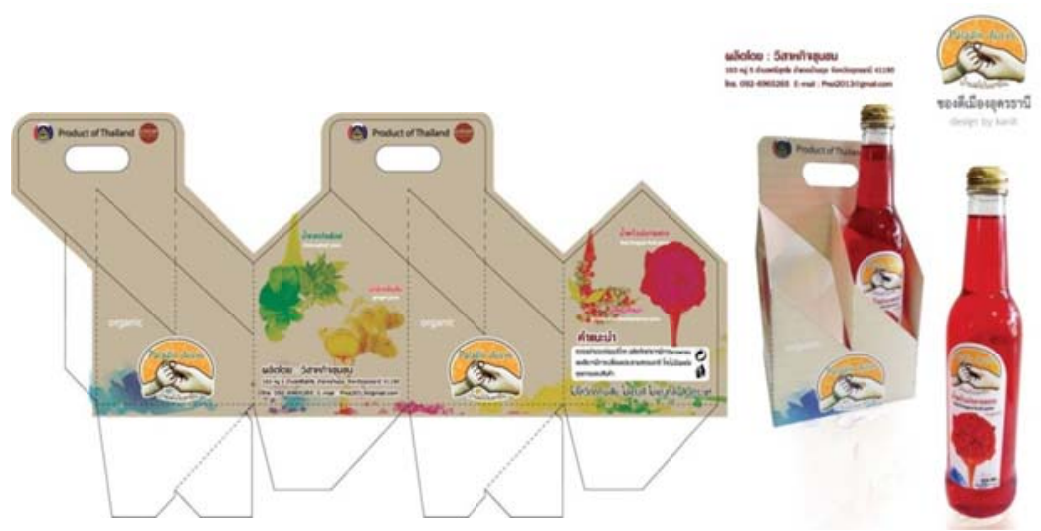

Figure 9. Packaging Model for Palah-Din Community-Enterprise Group. Palah-Din Community-Enterprise Group and Tida-Nakin Community-Enterprise Group produce juice

3. The assessment result of the market test about trademark and packaging of the community enterprises in Ban Dung district in Udonthani province is elucidated as: 
Table 1. Community Enterprises’ Satisfaction towards Packaging Model Assessment

\begin{tabular}{llccc}
\hline No. & List & Mean & S.D. & Level of Satisfaction \\
\hline 1. & Trademark suits product properly and beautifully. & 4.83 & 0.37 & Highest \\
2. & Form and pattern of package match the trademark and product. & 4.83 & 0.37 & Highest \\
3. & Package color is aesthetic and represents local arts. & 4.83 & 0.37 & Highest \\
4. & Package shape suits transportation. & 4.66 & 0.47 & Highest \\
5. & Package appearance suits showcase. & 4.83 & 0.37 & Highest \\
6. & Package can be given as gift and souvenir. & 5.00 & 0.00 & Highest \\
7. & Easy to use and suit product & 5.00 & 0.00 & Highest \\
8. & International and contemporary & 5.00 & 0.00 & Highest \\
9. & Clear product detail and can contact producer & 5.00 & 0.00 & Highest \\
& Total & 4.88 & 0.02 & Highest \\
\hline
\end{tabular}

Summary: According to the table 1, the evaluation result of community enterprises' satisfaction towards packaging model (the participant are 10 persons and 10 community enterprise groups) illustrates that there is the highest level of overall satisfaction towards community-enterprise product packaging (Mean=4.88), and the top satisfactions are regarding package can be given as gift and souvenir, easy to use and suit product, international and contemporary as well as clear product detail and can contact producer.

After appraising packaging model of community enterprises, the products are distributed at the producers' stores. The 400 citizens and travelers in Udonthani province which are a purposive sample from 2 well-known tourist attractions in Udonthani are conducted the survey of packaging need in order to acquire appropriate consumer demand information. The tourist places including:

1. The OTOP Civil-State store in the Udonthani international airport: the participants are citizens and visitors totaled 200 persons.

2. The Community Economic Service Center in Ban Dung district in Udonthani province: the participants are citizens and visitors totaled 200 persons.

Table 2. Udonthani Citizens’ and Visitors’ Satisfaction towards Packaging Model Assessment

\begin{tabular}{llccc}
\hline No. & List & Mean & S.D. & Level of Satisfaction \\
\hline 1. & Trademark suits product properly and beautifully. & 3.84 & 0.76 & High \\
2. & Form and pattern of package match the trademark and product. & 3.74 & 0.84 & High \\
3. & Package color is aesthetic and represents local arts. & 3.50 & 0.80 & High \\
4. & Package shape suits transportation. & 3.74 & 0.85 & High \\
5. & Package appearance suits showcase. & 3.89 & 0.73 & High \\
6. & Package can be given as gift and souvenir. & 4.13 & 0.76 & High \\
7. & Easy to use and suit product & 4.22 & 0.81 & High \\
8. & International and contemporary & 4.28 & 0.68 & High \\
9. & Clear product detail and can contact producer & 4.49 & 0.72 & High \\
& Total & 3.98 & 0.77 & High \\
\hline
\end{tabular}

Summary: It is noticeable from the result of Udonthani citizens' and visitors' satisfaction towards packaging model assessment (the participant totaled with 400 persons) that there is a high level of overall satisfaction towards community-enterprise product packaging (Mean=3.98) having a high satisfaction in all sections.

\section{Discussion of Research Result}

The trademark and packaging design of community enterprises in Ban Dung, Udonthani has a conclusion and recommendation involving to the research objectives as following:

1.1 The analysis of problems and marketing situation of the original community-enterprise products in Ban Dung in Udonthani depicted that the community product "Ban Dung Model" in Udonthani had chosen by the purposive selection method. The target group consisted of 10 groups of entrepreneurs which were: food and herb group, beverage group, appliance group as well as clothing group. Additionally, they should experience in producing community products at least 10 years. The requirements could be summarized as 1) distribution channels, every group emphasized a wholesaling to other shops inside and outside the province as well as 
opening booth in festivals; however, there were 3 groups of producers which had a new-generation leader, and sold merchandises via Facebook and Line. 2) The general problems which every group faced were budget-support scarcity as well as lacking of convenient transportation and out-of-date product appearance; therefore, the producers wanted relevant government sectors to help in developing products as well as acknowledging more information. Additionally, there are 2 groups of producer which were Kluay-City Organic Agricultural Group (Riceberry Rice Group in Ban Kluay) and Udon-Nakin Fabric Group. These producer groups could create new products; they also dared to initiate and trial to get new innovations. 3) The targeted things to improve were trademark as well as packaging.

The obstacles and marketing circumstances could be separated into 2 main factors which were the internal factor and external factor including:

Internal factor directly related to an upholder, and could be controlled more or less depending on proficiencies as well as resources which were results of strength and weakness of each group. It can be developed and solved in overall image as following:

1. Personnel factor: according to encouraging strength and unity to members in community enterprise, the Indoctrination to recognize the value of community handicrafts which could make money to oneself as well as family complied with Srikanlayanabut, A. (2007) explanation that the exhibiting experiences which were directly told by local residents to developers in order to make them know about local wisdom as well as value of local-wisdom learning. It was the primary condition to stimulate local participation existence.

2. Management factor: the community enterprise should always plan in advance for a month .The meeting should be held not less than 2-3 times in order to let members cooperatively make plans as well as discuss what to do, when, how, what equipment should be purchased, where to sell or about finance, accounting, income and expenditure issues. This related to Tinnabut, P. (1988).concept he claim that planning some factors which were the result of gathering preliminary information could provide a goal and delimitation to design something different from competitors which was advantageous to beat them by the better products or packages with the cheaper budget.

3. Marketing factor: the customer's demand and service approaches would be considered to respond satisfaction of users as well as make money concordantly. It involved with Soodsang, N. (2005) that the market test was testing the developed products about target group's satisfaction in order to contemplate its drawbacks, and solve them. In addition, the market test aims to find a consumer's activities regarding purchase, acceptance, decision, usability, re-purchase and market deal volume.

4. Packing, trademark and package factor: it was important to the community product distribution and selection. According to the basic development model, all groups should mainly focus on materials and primary cost. Furthermore, local material adaptation in producing product package could increase income to local people as well as create an outstanding and exotic packaging. Besides, it could also decrease a production cost. This was in accordance with what Kongjaroenkiat, P., \& Kongjaroenkiat, S. (1997) explained, under a serious competitive condition; the package had to be created by holding "catch the eye" concept in order to have an opportunity to attract target group's attention when it was put next to competitors' goods.

External factor is a variable which was affected from outers. It is apart from what the upholders could control by themselves; nevertheless, it could be protected.

1. Economic and Competitive factor: the community products had a high marketing competition between the stores settled in the same area as well as the shops run by private company. Consequently, the producers had to maintain product quality and standard price which could correspond with the community and place for selling. This mentioned factor is related to Kongjaroenkiat, P., \& Kongjaroenkiat, S. (1997) that the packaging design had to consider marketing principles and techniques including achievement setting, strategy management, marketing planning, sales promotion, etc. Moreover, the product arrangement as well as shop atmosphere had to be concerned. Planning shop to sale was the first factor in design principle, such as selling in a fresh-food market or in department store.

2. Resource and Technology factor: the resources in Ban Dung community enterprise were mostly the local materials, and the production was done by local people; therefore, it caused an inexpensive production cost. In the case of importing materials from outside area, they were still easy to find and not deficient. Meanwhile, the technologies used in this community were simple and they are inset the folk wisdom which could produce as well as fix by producers themselves. This was corresponding with Suksod, T. (2001) said, the materials and resources had to be used worthily, prudently and get the most out of. Besides, the producers should concern 
about material waste or environment destruction.

1.2 The trademark and packaging design of Ban Dung community enterprise in Udonthani allowed for 3 main sections which were:

1. Need / benefit: the trademark is a marketing necessity in capturing consumer attention by its brand name as well as logo. Mostly, the Ban Chiang community would underline the name which could represent the area, such as Kham Chanod, the Great serpent, the naga lord Sisotho in order to be easy to remember. The packaging was designed in order to utilize easily with an affordable production cost; moreover, it was able to protect the product as well as sell itself. Kongjaroenkiat, P., \& Kongjaroenkiat, S. (1997) indicated that the purpose of packaging were protecting, wrapping, bearing while transporting, being the media for giving information and description to consumers and marketing distributing.

2. Form: there were 3 principles in creating trademark and package involving graphic design factor which were unity, balance and dominance to clarify the trademark pattern as well as had an identity which relates to the brand name. There was a visible part on packaging to show merchandise inside in order to efficiently gain consumers' decision. Furthermore, the package design was created to present the local art; for example, the Thai loincloth package was designed its graphic as a farmer by having a space at the famer's waist to show the Thai loincloth due to the girdle popularity or round bamboo basket (Cha-Lorm) which E-san people used for stocking things in traveling was resized to fit native woven fabric. This made product have a striking identity. The beverage packages were designed as a set because there were various flavors of juice and other drinks; hence, the graphic or bottle form design should be similar in one set in order to avoid consumer's confusion in purchasing merchandise. Artitkawin, A. (2016) said the packaging had to consist of target-group setting, name specification and product tag design. Planning materials, product shape, color and graphic were also important. Additionally, studying related literatures would make products more worthy, attractive and interesting as well as increase merchandise price. According to Mekhum, W., \& Rungsrisawat, S. (2017). Also it is necessary to focus state support measures on marketing, technological, education and legal support of small business in the province. In our opinion, inexpensive, but effective tool to support the competitive background in the province could be an opening (on the basis of, for example, Suan Sunanda Rajabhat University) of service center for legal and accounting support of provincial business (providing all financial and contractual functions online), formation and promotion of the regional brand, which has to include the most competitive and promising in terms of foreign goods and services markets expansion. This center could also serve as a platform for the exchange of technologies, business ideas and best practices.

According to Prachuabsuk, J., Sirisom, J., \& Phonnikomkij, N. (2015). This research offered the samples of label and package of rice product for commercial utilization. It can be extended to those agriculturists who grow rice for sale and promote their collective activities in marketing promotion for raised income of their groups, thus giving the sense of pride in their own products and also more choices for consumers. It provided guidelines to agriculturists in the distribution of their rice products. They can exchange and share marketing business knowledge, and ensure that rice quality meet the agricultural quality standards, and that rice were well selected to serve those health conscious group of consumers on social media and other channels as well.

3. Technology: the production technology in the overall image used the digital printing whilst packaging structure used both ready-made and handcraft package because they were durable, strong and cheaper than ordering box production. This made producers be able to buy instant production easily, and printing graphic sticker was affordable.

1.3 The market test evaluation on community-enterprise trademark and package development in Ban Dung district, Udonthani described regarding the packaging model assessment result conducted survey by the community enterprises including 10 persons and 10 community enterprises that there was the highest level of overall satisfaction towards community-enterprise product packaging ( Mean =4.88), and the top satisfactions were regarding package can be given as gift and souvenir, easy to use and suit product, international and contemporary as well as clear product detail and can contact producer.

The result of Udonthani citizens' and visitors' satisfaction towards packaging model assessment (the participant totaled with 200 persons) that there was a high level of overall satisfaction towards community-enterprise product packaging (Mean $=3.98$ ) having a high satisfaction in all sections.

According to the survey results, the producers of community enterprises had a higher level of satisfaction that that of citizens and travelers in Udonthani province. Both participant groups had similar satisfaction opinion regard to can contact producer which could illustrate that the description on package about a producer contact was clear, and the graphic composition design was appropriate. However, the lowest level of satisfaction 
between community enterprise group and user group came from different sections; the least satisfaction of former group was package shape suits transportation whereas that of the latter group was package color is aesthetic and represents local arts. Notably, it was due to the fact that the community enterprise group did not only produce product, but also sent products to shops. If the packages were not suitable for transportation, the products inside would be damaged. Moreover, the customers may complain about blemish goods which effectuated the selling difficulty meanwhile the users would always firstly emphasize product beauty. According to Soodsang, N. (2016) described, the model development of Thai Rice Label and Package for Heath Conscious Group of Consumers on Social Media. It can be extended to those agriculturists who grow rice for sale and promote their collective activities in marketing promotion for raised income of their groups, thus giving the sense of pride in their own products and also more choices for consumers. It provided guidelines to agriculturists in the distribution of their rice products. They can exchange and share marketing business knowledge, and ensure that rice quality meet the agricultural quality standards, and that rice were well selected to serve those health conscious group of consumers on social media and other channels as well.

\section{Acknowledgments}

This research was supported by Suan Sunandha Rajabhat University.

\section{References}

Artitkawin, A. (2016). The Packaging Development and Projecting Positive Product Image of Appliance, Decoration and Souvenir of Community Entrepreneur: The Case Study. Journal of Modern Management Science Lampang Rajabhat Universityyear, 9(2), July-December 2016.

Kiadthong, T. (2005). Logo Design. Bangkok: Sipprapa Press.

Kongjaroenkiat, P., \& Kongjaroenkiat, S. (1997). Food Packaging. Bangkok; Department of Industry Promotion.

Mekhum, W., \& Rungsrisawat, S. (2017). Local Business for Regional Competitiveness: The Case of Samut Songkhram, Thailand. Aktual'ni Problemy Ekonomiky= Actual Problems in Economics, 189, 194. http://search.proquest.com/openview/5d7a6d34ee747e476dfd802da1e7a9b6/1?pq-origsite=gscholar\&cbl=2 035679

Prachuabsuk, J., Sirisom, J., \& Phonnikomkij, N. (2015). Effect of Strategic Cost Management on Operational Efficiency of Packaged Production Business in Thailand. Journal of Humanities and Social Sciences, Mahasarakham University, 33(1).

Soodsang, N. (2005). The Study of Industrial Product Design. Bangkok: Odeon Storepress.

Soodsang, N. (2016). A Model Development of Thai Rice Label and Package for Heath Conscious Group of Consumers on Social Media. Asian Social Science, 12(6), 1-6. https://doi.org/10.5539/ass.v12n6p217

Srikanlayanabut, A. (2007). Graphic Design Printing \& Publishing. Banbkok: Viscom Center CO, Ltd.

Suksod, T. (2001). The Industrial Product Design. Bangkok: Odeon Storepress.

Tinnabut, P. (1988). Packaging Design. Bangkok: Odeon Storepress.

\section{Copyrights}

Copyright for this article is retained by the author(s), with first publication rights granted to the journal.

This is an open-access article distributed under the terms and conditions of the Creative Commons Attribution license (http://creativecommons.org/licenses/by/4.0/). 